\title{
Research on the relationship between the demand for suburban bus transport and the number of registered passenger cars in the Slovak Republic
}

\author{
Vladimír Konečnýl, Mária Brídziková ${ }^{1 *}$, \\ ${ }^{1}$ University of Zilina, Faculty of Operation and Economics of Transport and Communications, \\ Univerzitna 1, 01026 Zilina, Slovakia \\ * corresponding author: maria.bridzikova@fpedas.uniza.sk
}

\begin{abstract}
In recent years a trend of increasing individual car transport is seen in the traffic at the expense of public passenger transport. This adverse development has negative effects on the environment and human health as well. This manuscript aims to prove the declining demand for bus transport in individual self-governing regions in the Slovak Republic and at the same time the increase in the share of individual car transport. The increase in individual car transport has, above all, a negative impact on passenger demand for ordinary fares, as the population has the choice of using the services of a particular operator or their own passenger car to make their journeys. From the side of government or individual self-governing regions as contracting authority of transport services must be an effort to reverse this unfavorable situation, as the number of registered passenger cars is one of the important factors that affects the demand for suburban bus transport. The authorities can support suburban bus transport in front of the individual car transport through strategic documents such as „Strategic plan for the development of public passenger transport".
\end{abstract}

Keywords: demand, individual car transport, suburban bus transport, passenger car.

JEL Classification: $L 91, L 92, O 18, R 41, R 42$.

\section{Introduction}

Transport is considered to be on of the major contributors to environmental pollution (greenhouse gas emissions, noise, accidents, depletion of natural resources). Transport system are currently associated with many problems and cannot be considered as sustainable (Malin and Khan, 2020), (Jařábek et al., 2016).

Transport demand is dynamic because it varies with time and is not homogeneous since it includes different subgroups of passengers, who differ in their characteristics, requirements, and expectations (Profillidis and Botzzoris, 2019). The trend in recent years has been a decline in passengers in the public transport system (Swianiewicz and Brzóska, 2020). The impact of public transport unreliability on passenger demand was studied by Oort et al. (2014)-. Efthymiou and Antoniou (2017) addressed the effects of the Athens economic crisis on the satisfaction and demand for public passenger transport users, where the results point to an increased share of public passenger transport use after the economic crisis compared to individual car transport. 
Buehler and Pucker (2021) analyzed the factors influencing public passenger transport demand in Germany and in the U.S. and found dependence on demographic, socio-economic, and territorial characteristics. They also pointed out that passengers in Germany were five times more likely to use public transport services on their journey than passengers in the U.S. Daldoul et al. (2016) described the key factors that influence passengers' decision whether to use public transport or not. Cordera et al. (2015) examined the impact of unemployment and income on public passenger transport demand in Spain. They found out that unemployment affects the demand for transport with an elasticity between 0.133 and 0.210 and income with an elasticity between -0.505 and -0.861. Polat (2012), Paulley et al. (2006), Metz (2012), Gonzáles et al. (2020) have also addressed in their research the demand factors by which operators and service providers can influence the demand for public passenger transport to some extent.

It is important to realize that, on the one hand, the demand for public transport is declining, but on the other hand, the share of individual car transport is increasing. In the current trend, it is very important to examine what would lead individual transport users to switch to a public passenger transport system. Redman et al. (2013) pointed out in their research that while public transport users consider reliability and frequency to be important factors, individual car transport drivers consider their own perception and motivation to change to public transport.

This manuscript aims to analyze the development of demand in the field of public passenger transport in individual self-governing regions in the Slovak Republic and at the same time to analyze the number of registered passenger cars. We assume that with the increase of registered passenger cars, the demand for public passenger transport for the passenger group which travels for ordinary fares decreases. Subsequently, by applying correlation analysis (correlation coefficient), we verify the assumption.

\section{Methodology, methods used and data}

\subsection{Data on the number of passengers}

Data on the number of transported passengers for individual self-governing regions are available to contracting authorities. We managed to obtain the data for the entire Slovak Republic from the statistics of the Yearbook of Transport, Posts, and Telecommunications, from the source of the Statistical Office of the Slovak Republic. Based on the given data, we can monitor the development of demand for suburban bus transport in particular selfgoverning regions. At the same time, we can monitor the development of demand of individual groups of passengers for suburban bus services.

\subsection{Data on the number of registered cars}

Data on the number of registered passenger cars in the Slovak Republic are obtained from the Ministry of Interior of the Slovak Republic. Using the data, we examine car ownership in the whole Slovak Republic, and in the individual self-governing regions. To examine the demand factor (number of registered cars) and identify its impact on the demand of a selected group of passengers, we will use the growth rate method of correlation analysis. 


\subsection{Average growth rate}

The average growth rate coefficient expresses the average growth coefficient of the time series from the values from 1 to $\mathrm{n}$.

$$
\overline{K_{t}}=\sqrt[n-1]{\frac{y_{n}}{y_{1}}}
$$

where: $\mathrm{n}$ - number of time series elements,

$\mathrm{y}_{1}$ - the value of the first element of the time series,

$\mathrm{y}_{\mathrm{n}}$ - the value of the $\mathrm{n}$-th element of the time series.

\subsection{Correlation analysis}

Correlation analysis is an important tool for examining the relationships between socioeconomic phenomena. The tool of correlation analysis is the correlation coefficient (rx,y), which measures the statistical linear dependence between the values of the variables $\mathrm{X}$ and Y.

$$
r_{x, y}=\frac{n \cdot \sum x y-\sum x \cdot \sum y}{\sqrt{\left[n \cdot \sum x^{2}-\left(\sum x\right)^{2}\right] \cdot\left[n \cdot \sum y^{2}-\left(\sum y\right)^{2}\right]}}
$$

where: $\mathrm{n}$ - number of arranged pairs,

$\mathrm{x}$ - variable $\mathrm{x}$ (number of registered passenger cars),

$\mathrm{y}$ - variable y (number of passengers transported).

\section{Results}

\subsection{Development of the number of transported passengers in public passenger transport}

In the conditions of the Slovak Republic in recent years, the demand for services in public passenger transport has oscillated. Based on data kept by Statistical Office, we record a decline in the public passenger transport sector (suburban bus transport, urban public transport, rail transport). In 2006, the system transported 852 million passengers, in 2019 only 702 million, which represents a decrease of almost $18 \%$. From a regional point of view, the number of transported passengers is declining for the period 2013-2019. In the given regions, we record a decrease in demand in 2019 compared to 2013 from 14\% (Košice region) to $24 \%$ (Prešov region).

On average, the year-on-year demand for the observed period 2013-2019 calculated according to relation (1), decreased from $-2.63 \%$ (Košice region) to $-4.55 \%$ (Prešov region). There is a year-on-year decrease in the group of passengers for student and ordinary fares, while demand has a growing trend for the group of passengers for other fares. Only in the Nitra and Prešov regions in the given group of passengers did demand decrease by $1.69 \%$ and $0.45 \%$ year-on-year - see Table 1 . 
Table 1. Average year-on-year development of transported persons in the period 2013-2019 for individual self-governing regions.

\begin{tabular}{|c|c|c|c|}
\hline Region & Fare & $\begin{array}{l}\text { Coefficient of } \\
\text { average growth } \\
\text { rate }\end{array}$ & $\begin{array}{c}\text { Increase / decrease } \\
{[\%]}\end{array}$ \\
\hline \multirow{4}{*}{ Trnava region } & Ordinary fare & 0.9670 & -3.30 \\
\hline & Student fare & 0.9553 & -4.47 \\
\hline & Other fares & 1.0055 & 0.55 \\
\hline & Overall & 0.9662 & -3.38 \\
\hline \multirow{4}{*}{ Nitra region } & Ordinary fare & 0.9642 & -3.58 \\
\hline & Student fare & 0.9498 & -5.02 \\
\hline & Other fares & 0.9831 & -1.69 \\
\hline & Overall & 0.9610 & -3.90 \\
\hline \multirow{4}{*}{ Trenčín region } & Ordinary fare & 0.9542 & -4.58 \\
\hline & Student fare & 0.9565 & -4.35 \\
\hline & Other fares & 1.0187 & 1.87 \\
\hline & Overall & 0.9631 & -3.69 \\
\hline \multirow{4}{*}{ Žilina region } & Ordinary fare & 0.9593 & -4.07 \\
\hline & Student fare & 0.9561 & -4.39 \\
\hline & Other fares & 1.0352 & 3.52 \\
\hline & Overall & 0.9676 & -3.24 \\
\hline \multirow{4}{*}{$\begin{array}{c}\text { Banská Bystrica } \\
\text { region }\end{array}$} & Ordinary fare & 0.9676 & -3.24 \\
\hline & Student fare & 0.9504 & -4.96 \\
\hline & Other fares & 1.0010 & 0.10 \\
\hline & Overall & 0.9655 & -3.45 \\
\hline \multirow{4}{*}{ Košice region } & Ordinary fare & 0.9698 & -3.02 \\
\hline & Student fare & 0.9649 & -3.51 \\
\hline & Other fares & 1.0188 & 1.88 \\
\hline & Overall & 0.9737 & -2.63 \\
\hline \multirow{4}{*}{ Prešov region } & Ordinary fare & 0.9534 & -4.66 \\
\hline & Student fare & 0.9451 & -5.49 \\
\hline & Other fares & 0.9955 & -0.45 \\
\hline & Overall & 0.9545 & -4.55 \\
\hline
\end{tabular}

Source: Authors

\subsection{Development of the number of registered passenger cars}

The number of registered passenger cars is increasing every year in each European country. The increasing number of registered cars, together with the rising minimum wage or senior pension, means that the inhabitants use their cars rather than public passenger transport to satisfy their transport needs. One of the main reasons is the shorter relocation time and comfort.

Within the Slovak Republic, the number of registered passenger cars is increasing every year. In 2006, only 1.84 million cars were registered, but in 2019 there were 3.29 million cars, which represents an increase of $78.48 \%$. The share of passenger cars in the total number of registered vehicles is growing every year - see Figure 1. 


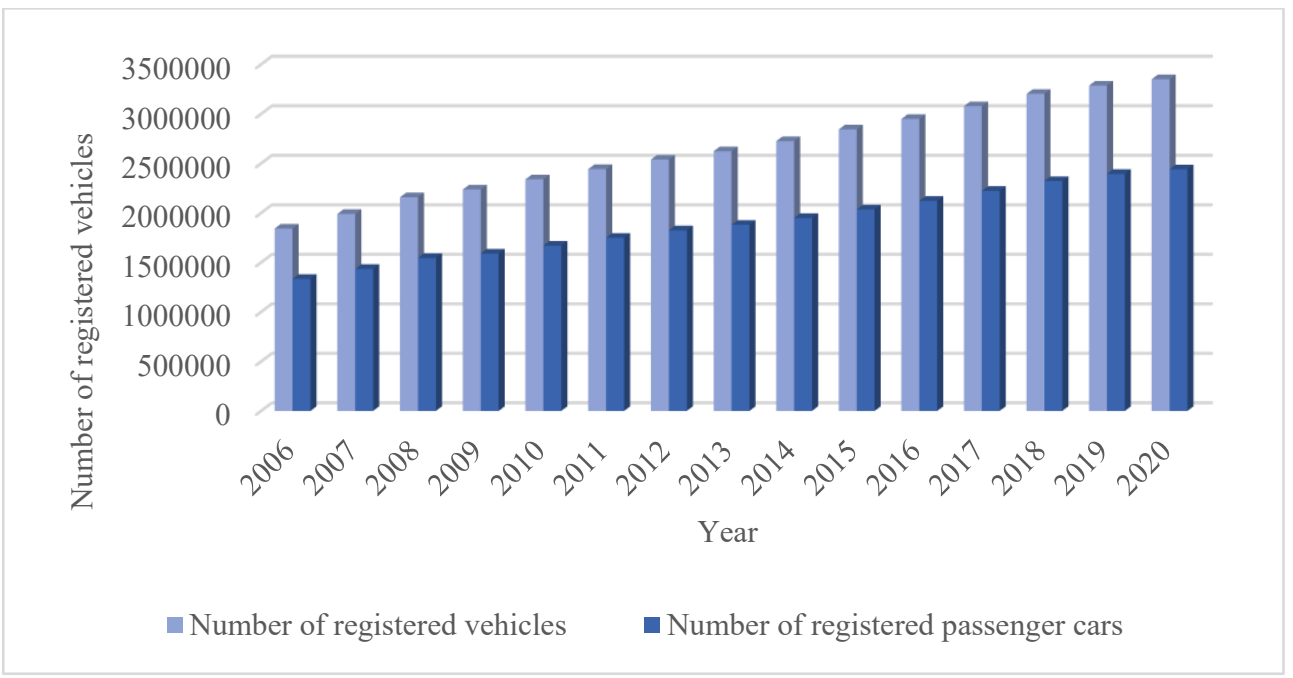

Figure 1. The number of registered vehicles and passenger cars in the Slovak Republic

Source : Drawn by the authors on the basis of [14]

On average, the number of registered passenger cars increased year-on-year in the observed period of 2013-2019, calculated according to relation (1). The smallest year-onyear increase was in the Banská Bystrica region (3.40\%), while the largest increase was recorded in the Žilina region (4.44\%) - see Table 2.

Table 2. Average year-on-year increase of registered passenger cars in self-governing regions.

\begin{tabular}{|l|c|c|}
\hline \multicolumn{1}{|c|}{ Region } & $\begin{array}{c}\text { Average growth rate } \\
\text { coefficient }\end{array}$ & Increase/decrease [\%] \\
\hline Trnava region & 1.0405 & 4.05 \\
\hline Nitra region & 1.0389 & 3.89 \\
\hline Trenčín region & 1.0370 & 3.70 \\
\hline Žilina region & 1.0444 & 4.44 \\
\hline Banská Bystrica region & 1.0340 & 3.40 \\
\hline Košice region & 1.0385 & 3.85 \\
\hline Prešov region & 1.0428 & 4.28 \\
\hline
\end{tabular}

Source: Authors

\subsection{Investigation of the relationship between the demand factor (number of passenger cars) and the demand for suburban bus transport in given regions}

Various statistical software is currently used to process large data in a relatively short time. In this research, we focused not only on the calculation of the correlation coefficient but also on whether there is a statistically significant linear relationship between the variables. The decision (where there is or isn't a statistically significant linear relationship between the variables) is made according to the p-value of the test. An important step is to define a null hypothesis $\mathrm{H} 0$ : between y (the number of passengers carried for ordinary fare) and $\mathrm{x}$ (the number of registered passenger cars), which means there is no statistically significant linear dependence. The alternative hypothesis H1: between y (the number of 
passengers transported for ordinary fares) and $\mathrm{x}$ (the number of registered passenger cars) means there is a statistically significant linear dependence. We chose the significance level $\alpha$ $=0.05$. In the last step, we define a $p$-value, where if:

- $\quad p$-value $>\alpha-$ we do not reject H0;

- $\quad$-value $<\alpha$ - we reject H0 and accept H1.

The calculated correlation coefficients and the value of statistical significance are given in Table 3. In the case of all self-governing regions, the $\mathrm{p}$-value is $<\alpha$, so we reject $\mathrm{H} 0$ and accept $\mathrm{H} 1$. There is a statistically significant linear relationship between $\mathrm{y}$ and $\mathrm{x}$ (the number of passengers transported for ordinary fare and the number of registered passenger cars). In regions, the correlation coefficient reaches a value from -0.9238 (Nitra region) to -0.998 (Košice region) - which means a strong indirect relationship. The correlation coefficient shows that the number of registered passenger cars increases, and the number of transported passengers for ordinary fares decreases.

Table 3. Correlation coefficients and p-values for observed regions

\begin{tabular}{|l|c|c|}
\hline \multicolumn{1}{|c|}{ Region } & Correlation coefficient & p-value \\
\hline Trnava region & -0.9946 & 0.000004 \\
\hline Nitra region & -0.9238 & 0.002959 \\
\hline Trenčín region & -0.9901 & 0.000018 \\
\hline Žilina region & -0.9949 & 0.000004 \\
\hline Banská Bystrica region & -0.9389 & 0.001713 \\
\hline Košice region & -0.998 & 0.0000003606 \\
\hline Prešov region & -0.9742 & 0.000202 \\
\hline
\end{tabular}

Source: Autors

\section{Discussion}

Every year, the number of passenger cars is increasing. In the 2020, the ratio ranged from 499 to 353 passenger cars per 1,000 inhabitants - see Figure 2.

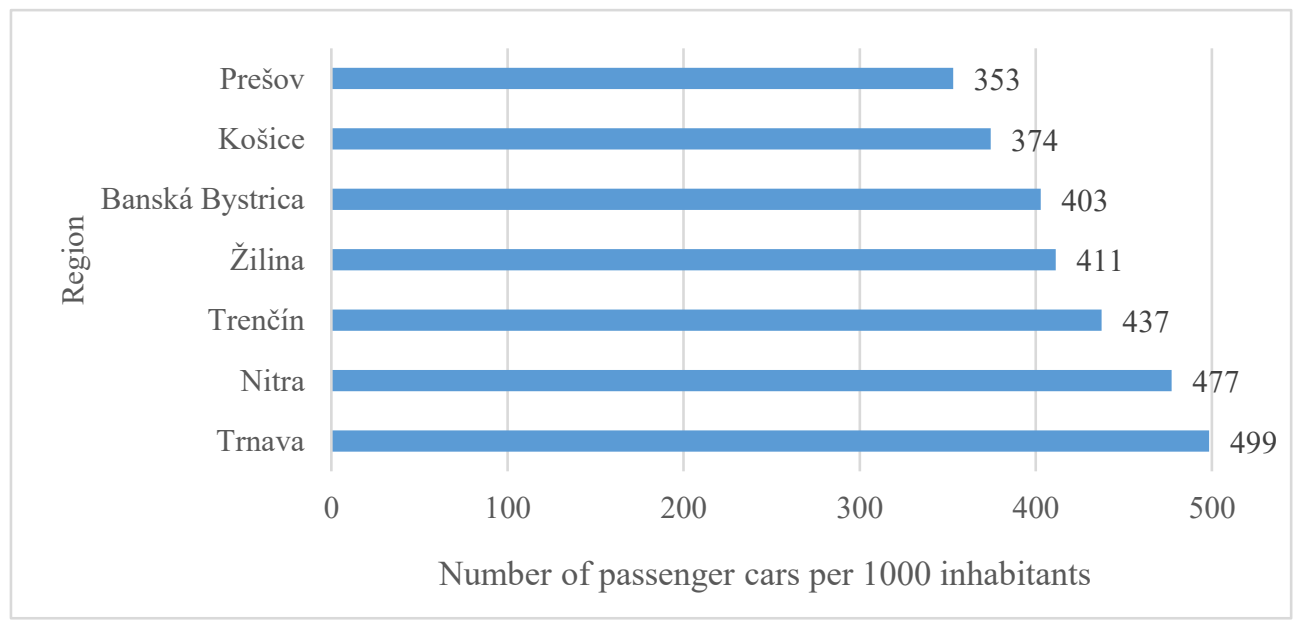

Figure 2. The ratio of passenger cars per 1,000 inhabitants in 2020 within the Slovak Republic 
Source : Autors

The growing number of passenger cars is a significant factor in demand since it strongly determines the demand for travel for ordinary fares. Not only has the number of passengers decreased in recent years, but the structure of passengers has changed. Every year, the number of passengers transported for ordinary fares decreases, but on the contrary, the number of passengers transported for other fares increases. Holders of disabled people's licenses, citizens over the age of 70 years are listed as people transported for other fares - see Figure 3.

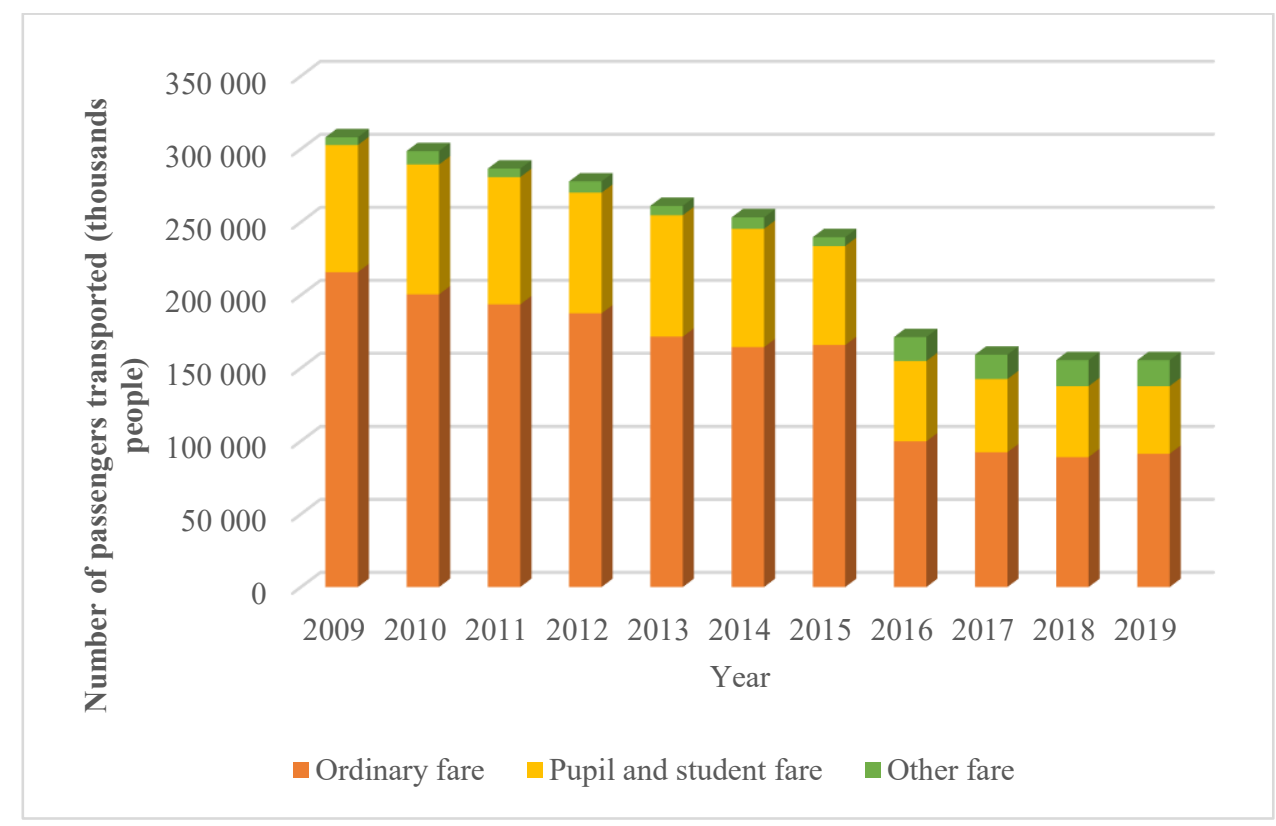

Figure 3. The development of the number of passengers by the type of a ticket

Source : Drawn by the authors on the basis of [15]

The declining demand for the passengers transported for ordinary faes causes problems in financing suburban bus transport. Efficient transport systems are a key element for modern cities. The degree of overall productivity, wealth, and income distribution depends on the extent to which the urban transport system works. Organized, efficient, and sustainable transport systems can also create other positive effects, such as greater efficiency in the use of public space and urban infrastructure, reduction of pollution, and energy consumption Lohrey and Creutzing (2016), Lyons (2018), Zawieska and Pieriengud (2018), Czczuraszek and Chmlielewski (2018), Poliak et al.(2021), Kalašová et al.(2018), Poliak et al.(2020), Nedeliaková et al.(2014).

\section{Conclusion}

The research showed there is a statistically significant linear relationship between the demand (number of passengers transported for ordinary fares), and the number of registered passenger cars. In all cases, the correlation coefficient achieves a strong indirect relationship, which shows the growing trend in the number of registered cars has an impact on the declining demand for passengers transported for ordinary fares. This fact is important for 
authorities, as they should take further measures to stop the growing trend. At the same time, the measures taken to support suburban bus transport should help to improve the quality of transport services, which can stimulate demand for groups of passengers who are depending on bus transport (pupils and students, pensioners). In the future, it will be necessary to examine passenger demand for ordinary fares and the ownership of passenger cars in other countries, e.g. in V4 countries. One of the limiting elements of the research is the insufficient size of the data, as the data are only analyzed in the Slovak Republic. Furthermore, it is very important to expand the individual demand factors and also to examine the relationship between demand and individual demand factors in other modes of public transport - not only in bus transport.

\section{Acknowledgements}

The contribution was elaborated with the support of the Ministry of Education of the Slovak Republic: VEGA no. 1/0245/20 Poliak, M.: Identifying the impact of changes in transport legislation on the competitiveness of carriers and transport safety.

\section{References}

1. Malin,A.,\& Khan,J. (2017). Strategic use of green public procurement in the bus sector : Chalanges and opportunities. Journal of Cleaner Production, 164, 250-257.

2. Jeřábek,K., Majercak,P., Klieštik,T., \&Valaskova,K.(2016). Application of Clark and Wright's savings algorithm model to solve routing problem in supply logisticts. Nase More, 63(3), 115-119.

3. Profillidis,A.,\& Botzzoris,G.N. (2019). Modeling of transport demand. Analyzing, calculating, and forecasting transport demand. ISBN 978-80-554-1444-7.

4. Swianiewicz,P.,\& Brzóska,A. (2020). Demand elascitity for local public transport in Polish cities: Do local policies matter. Transylvanian Review of Administrative Sciences, 61, 125-142.

5. Van Oort,N., Brands,T., de Romph,E.,\& Flores,J. (2014). Imcomporatiing unreliability of transit in transport demand models : Theorethical and practical approach. Prepared for the 93rd Annual Meeting of the Transportation Research Board.

6. Efthymiou,D.,\& Antoniou,C. (2017). Understanding the effects of economic crisis public user 's satisfaction and demand. Transport Policy, 53, 89-97.

7. Buehler,R.,\& Pucher,J. (2012). Demand for public transport in Germany and the USA : An analysis of rider characteristics. Transport Reviews, 32(5).

8. Daldoul,M., Jarboui,S.,\& Dakhlaoui,A. (2016). Public transport demand : dynamic panel analysis. Transportation, 43, 491-505.

9. Cordera,R., Canales,C., dell'Olio,L.,\& Ibeas,A. (2015). Public transport demand elasticities during the recessionary phases of economic cycles. Transport Policy, 42, 173-179.

10. Polat,C. (2012). The demand determinants for urban public transport services : A review of the literature. Journal of Applied Sciences, 12, 1211-1231.

11. Paulley,N., Balcome,R., Mackett,RL., Titheridge,H., Preston,J., Wardman,M., Shires,J.,\& White,P. (2006). The demand for public transport: The effects of fares, quality of services, income and car ownship. Transport Policy, 13, 295-306.

12. Metz,D. (2012). Demographic determinants of daily travel demand. Transport Policy, $21,20-25$. 
13. Toro-González,D., Cantillo,V.,\& Cantillo-Garcia,V. (2020). Factors influencing demand for public transport in Colombia. Research in Transportation Business\&Management, 36.

14. Redmand,L., Friman,M., Gärling,T.,\& Harting,T. (2013). Quality atributtes of public transport that attract car users : A research review. Transport Policy, 25, 119-127.

15. Ministry of interior of the Slovak Republic. [online]. Available on : < https://www.minv.sk/?celkovy-pocet-evidovanych-vozidiel-v-sr>.

16. Yearbook of Transport, Posts and Telecommunications in 2006 to 2019. [online]. Available on : < https://slovak.statistics.sk>.

17. Lohrey,S.,\& Creutzing,F. (2016). A "sustainability window" of urban form. Transportation Research Part D : Transport and Environment, 45, 96-111.

18. Lyons,G. (2018). Getting smart about urban mobility - Aligning the paradigms of smart and sustainable. Transportation Research Part A : Policy and Practice, 115, 4-14.

19. Zawieska,J.,\& Pieriengud,J. (2018). Smart city as a tool for sustainable mobility and transport decarbonisation. Transport Policy, 63, 39-50.

20. Szczuraszek,T.,\& Chmlielewski,J. (2018). Sustainable transpor development and passenger transport demand in Poland. MATEC Web of Conferences.

21. Poliak,M., Svabova,L., Konečný,V., Zhuravleva, N.A.,\& Čulík,K. (2021). New paradigms of quantification of economic efficiency in the transport sector. Oeconomia Copernicana, 12(1), 193-212.

22. Kalašová,A., Čulík,K.,\& Kubíková,S. (2018). Smart city - Model of sustainable development of cities. XI International Science-Technical Conference Automotive Safety, 1-5.

23. Poliak,M., Poliaková,A.,\& Čulík.K. (2020). Impact of the social law on truck parking sustainability in the EU. Sustainability, 12(22), 1-16.

24. Nedeliaková,E., Nedeliak,I.,\& Majerčák,P. (2014). Research of services quality after the end of transportation in railway freight transport. Proceedings of 2nd International Conference on Management Innovation and Business Innovation (ICMIBI 2014), 54-61. 